\title{
'In the thick of every battle for the cause of Labor': the Voluntary Work of the Labor Women's Organisations in Western Australia, 1900-70.
}

\section{Bobbie Oliver}

This paper examines the voluntary contribution of the Labor women's organisations in Western Australia from 1900 until the end of the 1960s. It discusses the various voluntary contributions of the women to the ALP and the wider community and the motivation for these activities. In particular, it examines the women's struggle for equal representation within the Party. The paper concludes with an assessment of the contribution of this work to the development of the ALP and to the Western Australian community. By the early 1970s, women's organisations, both inside and outside of the ALP, began adopting more militant tactics to gain social, political and economic equality for women, assisted at last by a commitment from the ALP and the Trades and Labor Council. Consequently the year 1970 provides a logical point at which to conclude a study of this type of work by Labor women.

The organised labour movement in Western Australia survived and thrived on the efforts of volunteers. ${ }^{1}$ Before the 1950 s, only the ALP State Secretary, the Secretary of the Metropolitan District Council of the ALP, Members of Parliament, and a few union secretaries and organisers were paid. All other workers, both male and female, carried out their official tasks in their spare time, either while holding down fulltime and often physically exhausting jobs, or being engaged in full-time home duties. This article describes the various voluntary contributions that the members of the Labor women's organisations made to the ALP: electioneering; organising; community service; serving on committees to improve the rights, status and working conditions of women and young people; making layettes for babies of poor working families; providing clothing parcels during the Depression, and serving lunches to institutionalised 'orphans'. It discusses the broad nature and significance of voluntary work undertaken by the women in the labour movement. The paper concludes with an assessment of the contribution of this work to the development of the ALP and to the wider community in Western Australia.

Firstly, however, it is useful to look at the ways that the Labor women and their work may be said to fit the description of 'volunteers' and 'voluntary work'. As Melanie Oppenheimer has observed, 'identifying, labelling and categorising voluntary organisations within our society today is often tendentious, confusing and unstable' ${ }^{2}$ Similarly, Joanne Scott has asked whether those who work for noncharitable organisations can be classed as volunteers. ${ }^{3}$ There are also questions of who and why. What kinds of people undertake voluntary work and what motivates them to do so? Oppenheimer's finding that a major reason that people in the 1990s carried out voluntary work was 'altruism, or a feeling of social concern and responsibility for others ${ }^{4}$ applies to the Labor Women's Organisation (LWO) in the early and mid-twentieth century. Despite the 'Lady Bountiful' image, volunteers were not exclusively middle class or female. Sociologist Cora Baldock has produced 
a profile of volunteers working in the welfare sector in Australia as mainly female, older, European or Australian by birth, and with a 'substantial minority' being single. ${ }^{5}$ Baldock's volunteer profile fits the organisational membership of the LWO between the 1920s and the 1970s with a fair degree of accuracy. The main difference is that, while many of Baldock's volunteers were in paid employment, most LWO members were not.

Scott has raised some interesting issues in defining the parameters of voluntary work. While voluntary work could involve collecting and distributing clothes to the needy, for example, it could also involve lobbying federal, state and local governments by presenting submissions or forming deputations to discuss public concerns, such as the standard of education available to children in rural areas. Where, too, might the student of voluntarism locate 'career' volunteers who devoted as much time to unpaid work as a waged employee would spend at his or her full-time job ${ }^{6}$ The questions posed by Oppenheimer's and Scott's papers provide a useful starting point from which to examine the work of the Labor women's organisations in the early to mid-twentieth century. This paper applies Scott's 'broader definition' of voluntary work ${ }^{7}$ to the activities of the Labor women's organisations, which were not charities but branches of the Australian Labor Party (WA). The women's work involved industrial organising, lobbying, public education campaigns and electioneering, as well as collecting food and clothing parcels and fund raising. Likewise, Scott's examples of 'career' voluntary workers among Queensland women have many parallels among such Labor women as Mamie Swanton, Jean Beadle and Rose Fuhrmann. Who, then, were the Labor women and what was the nature of their work?

Mamie Swanton (1861-1940), the founder of the Coastal Tailoresses' Society, devoted her life to improving conditions within her own trade and in the wider labour movement. The tailoresses were among the first women unionised in Western Australia, with the Eastern Goldfields Tailoresses' Society being formed in 1899 and the Coastal Society the following year. Swanton knew that sweating of female and child labour was widespread in Western Australia as elsewhere in the Commonwealth. Acting as an unpaid union organiser, she visited girls and women in their workplaces and sat beside them, listening to their grievances as they stitched. She wrote numerous letters to the press and frequently spoke on public platforms to denounce the 'white slave trade' existing in the State. These activities jeopardised her own security and she was sacked several times. ${ }^{8}$ It was only after her persistent efforts that a Select Committee was appointed to inquire into the practice of sweating in Western Australian industries, but its report was disappointing. The Committee visited 34 factories and seven shops in Perth and Fremantle and interviewed 29 witnesses before concluding that 'sweating ... does not exist to the alarming extent that was commonly believed'. In fact, the Report stated, allegations of sweating often arose from a 'misconception' that women were forced by circumstances to undertake piecework in their homes. Actually, they did so 'not out of necessity, but in order to supplement the already sufficient incomes of their breadwinners' so as to 'supply themselves with objects of luxury or refinement'. '. Exploitation, it seemed, was only exploitation when women 'had' to work, or when large numbers of workers were involved.

'The Little Tailoress' - as workers affectionately called Swanton - battled on, accusing the labour movement of 'shamefully neglecting the women workers'. She

achieved a partial victory in with a standard wage and in sit on stools rather than st legislation to protect abando state maternity hospital, eq nurses. All this was achieve as a tailoress. ${ }^{10}$

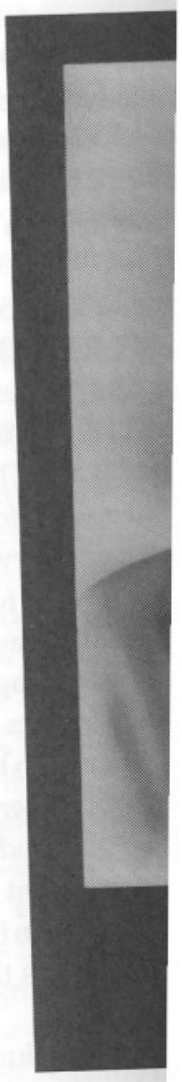

Jean Beadle (18 movem

Jean Beadle (1867-19 in Fremantle, in Octobe she became founding $\mathrm{P}$ December 1906) and a ALP. Under Beadle's lea in the Boulder electorat names to the Registrar. of the mining commun vote. ${ }^{11}$ The women's e presided over the first ' 
tor in Australia as mainly female, h a 'substantial minority' being sational membership of the LWO of accuracy. The main difference in paid employment, most LWO

ing the parameters of voluntary ting and distributing clothes to bbying federal, state and local ig deputations to discuss public able to children in rural areas. 'career' volunteers who devoted yee would spend at his or her er's and Scott's papers provide e work of the Labor women's iry. This paper applies Scott's tivities of the Labor women's s of the Australian Labor Party ing, lobbying, public education food and clothing parcels and $r^{\prime}$ voluntary workers among uch Labor women as Mamie $\mathrm{n}$, were the Labor women and

Coastal Tailoresses' Society, own trade and in the wider twomen unionised in Western ociety being formed in 1899 cnew that sweating of female stralia as elsewhere in the she visited girls and women ir grievances as they stitched. y spoke on public platforms . These activities jeopardised was only after her persistent into the practice of sweating appointing. The Committee mantle and interviewed 29 exist to the alarming extent ed, allegations of sweating forced by circumstances to so 'not out of necessity, but f their breadwinners' so as t. .9 Exploitation, it seemed, n large numbers of workers led Swanton - battled on, ; the women workers'. She

achieved a partial victory in 1907 when the Arbitration Court granted an award with a standard wage and improved conditions (such as allowing some workers to sit on stools rather than stand). Swanton worked for other reforms, too: state legislation to protect abandoned children, the establishment of widows' pensions, a state maternity hospital, equal pay for women and better working conditions for nurses. All this was achieved without any pay, other than that earned by her work as a tailoress. ${ }^{10}$

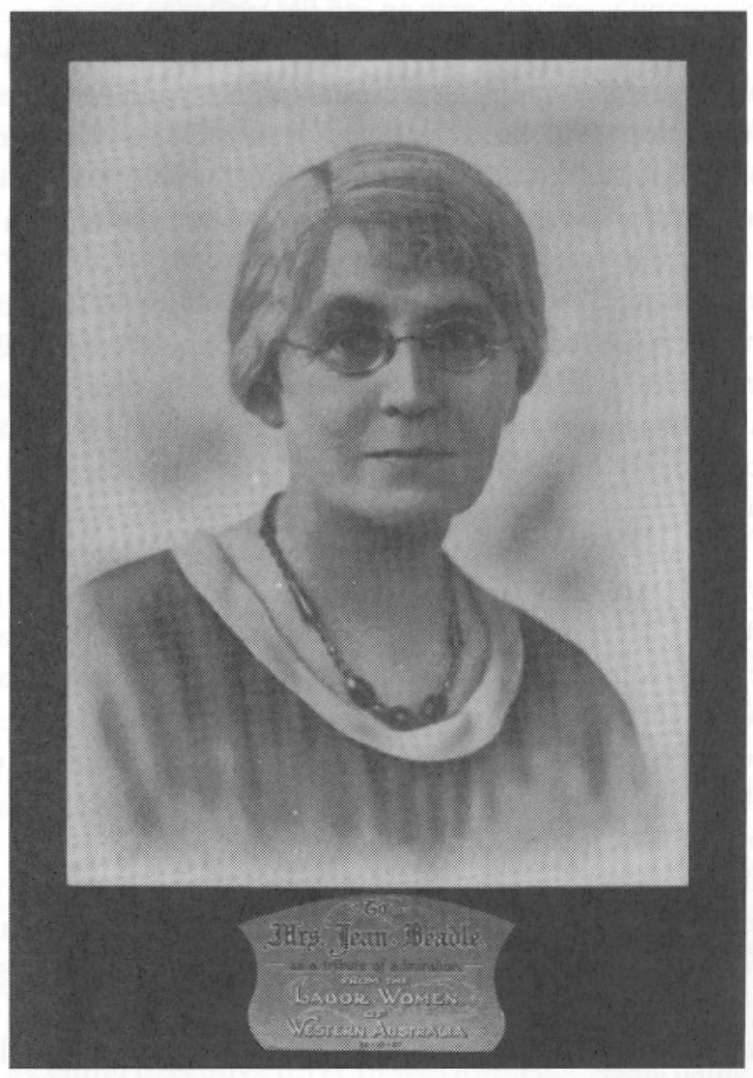

\section{Jean Beadle (1867-1942), a pioneer of the Western Australian labour movement. She made a career out of voluntary work. (Courtesy of the ALP, WA Branch).}

Jean Beadle (1867-1942) was a founder of the first Labor Women's Organisation in Fremantle, in October 1905. After moving to Boulder on the Eastern Goldfields, she became founding President of the Goldfields Women's Labor League (formed December 1906) and a delegate to the Eastern Goldfields District Council of the ALP. Under Beadle's leadership, the Goldfields women canvassed to get every adult in the Boulder electorate on the electoral roll and, by April 1907, had sent over 200 names to the Registrar. Most of these would have been new arrivals and members of the mining community, whose inclusion on the rolls would often swell the Labor vote. ${ }^{11}$ The women's efforts were rewarded with a Labor victory in 1911. Beadle presided over the first WA Labor Women's Conference in 1912. During World War I, 
she took an active part in the anti-conscription campaign. Throughout the 1920s and '30s, she held Executive positions in several Labor women's organisations. Her work in the wider community included serving as the Vice President of the Soldiers' Reception Committee during World War I. She was 'one of the most active and respected members' of the Women's Service Guild, ${ }^{12}$ a Justice of the Peace for 25 years, and a Special Magistrate for the Children's Court from 1915 to 1929. A foundation member of the Women Justices Association, Beadle was President from 1930 to 1938 . For many years, she was an official visitor to the women's section of the Fremantle Prison and a campaigner for better conditions for the inmates. She was involved in securing a Maternity Hospital in Perth, and served as secretary of its Advisory Board from 1921 until her death. Apart from a brief period as a paid organiser for the ALP Metropolitan District Council in 1918, Beadle received no remuneration except for some travelling expenses. She truly made a career out of voluntary work. ${ }^{13}$

Another woman who made a career of unpaid community work was Rose Fuhrmann, who served as Labor Women's Central Executive (LWCE) President in the 1950s, and represented WA at Labor Women's interstate conferences. Apart from her ALP commitments, Fuhrmann was foundation president of the Soroptimist Club in 1955 . She spent many hours doing voluntary community work. The mother of six children, she would rise at 5 am to perform her household tasks before spending the day doing voluntary work, then returning home to cook and serve the family meal in the evening. For 25 years, she performed voluntary work for the Child Welfare Department, serving on committees and organising Christmas parties and zoo picnics for fostered children. She was a co-founder of the Marriage Guidance Council, a Justice of the Peace, and a life member of the Women Justices Association and the Children's Protection Society. She was also the first woman to be elected to the Subiaco City Council, where she served for 16 years. In 1969, when she was in her 80 s, the Soroptimist Club of Stirling honoured her as their outstanding woman of the year. The Subiaco City Council announced that a new infant health and kindergarten centre would be named the Rose Fuhrmann Centre. When interviewed by the Daily News, Fuhrmann said that her one disappointment was that women still did not have equal pay. ${ }^{14}$ But she had received no pay at all.

The achievements of Swanton, Beadle and Fuhrmann show that voluntary work, broadly defined, might encompass many activities and make a significant contribution to society. But what motivated these women and how did they achieve their aims? In October 1933, the Labor women in Western Australia celebrated the twenty-first birthday of the Labor Women's Organisation (LWO), dated from the Labor Women's Conference in 1912. The Westralian Worker, celebrating their achievements, was confident of their motivation and aims:

During the period the Labor Women have given devoted service to the Movement which is essentially a humanitarian one, and has as its aims and ideals the bringing into being a better world. When women first took part in legislative matters they were sneered at and told that 'women's place is in the home'. The old idea that woman was the man's chattel lingered long and it was woman herself who shattered that idea when she proved her capacity and her ability to stand alongside the men and fight for the uplift of humanity... 
uroughout the $1920 \mathrm{~s}$ s organisations. Her dent of the Soldiers' he most active and of the Peace for 25 im 1915 to 1929 . A was President from women's section of or the inmates. She rved as secretary of ef period as a paid Beadle received no ade a career out of

ty work was Rose WCE) President in rences. A part from e Soroptimist Club rrk. The mother of ks before spending d serve the family rork for the Child istmas parties and larriage Guidance istices Association an to be elected to , when she was in tstanding woman infant health and Nhen interviewed was that women

t voluntary work, ke a significant I did they achieve lia celebrated the ), dated from the selebrating their

vice to the as its aims i first took 'women's I's chattel dea when men and
There is still much to be done and every reliance is placed in the Labor Women that they will carry on in the same untiring and enthusiastic manner which has distinguished the life of their organisation ...

With the Labor Movement of the State the Worker joins in tendering birthday greetings to the Labor Women's Organisation as a body, and individually to the women who have carried its banner in the thick of every battle for the cause of Labor. ${ }^{15}$

So the Westralian Worker saw the LWO as working for 'a better world' - which the organisation undoubtedly did - and as enabling women to work alongside men in the Labor movement. One suspects, however, that the comment 'there is still much to be done' referred to the achievement of a better world, rather than the progress of women in the labour movement. One third of the way through the century, women were still very poorly represented within the ALP, despite having been accepted as delegates of unions or other affiliated organisations, apparently on an equal footing with men. Much of the LWO's early effort was directed towards increasing women's representation in the Party.

\section{'Standing alongside the men'}

At first, the prospects seemed fairly bright. In the early years of the century, female delegates were often appointed as Treasurers or Auditors to the various Labor bodies. ${ }^{16}$ This practice may have arisen because, in many working class homes, wives undertook the management of finances. But it was soon abandoned. From 1910, very few women represented unions or party branches, and almost none held office on the State Executive or any of the District Councils. The women's organisations, therefore, provided the easiest way by which a woman could become a delegate of the ALP. By 1907, numerous women's leagues had formed around the State, although mostly in the Perth area. Unlike the men's groups, the women's branches usually met in private houses, the Subiaco Branch, for example, meeting at Mrs Bath's residence. One imagines, too, that they coped with constant interruptions from small children and babies. Subiaco reported in March 1907 that their group grew by two or three members each meeting. ${ }^{17}$

The Labor women did not have a State-wide organisation until 1927 when the Labor Women's Central Executive (LWCE) was formed. ${ }^{18}$ As its name indicates, the LWCE in relation to the women's organisations had a role parallel to that of the ALP State Executive over the District Councils, but enjoyed virtually none of the prestige. Two LWCE delegates had a seat on the ALP State Executive, but the role of women remained very much peripheral to the main male-dominated Labor organisation. Another avenue for voluntary work, that also provided a route to the ALP State Executive, was the ALP Peace Committee. By the end of the 1920s, peace rallies were commonplace in Australia, with a growing number of peace organisations using occasions such as Anzac Day and Armistice Day to educate the public about the horrors of war and to urge governments to seek other means of settling international differences. In 1929, the State Executive appointed an ALP Peace Committee, comprising three women and three men. Obviously, the LWCE did not regard this as a 'women's' committee because they formed their own Peace Committee to work alongside the ALP's organisation - but it was one of the few organisations represented by female delegates on the State Executive. ${ }^{19}$ Why the 
State Executive accepted so many female delegates on the Peace Committee is not clear from the records.

The first Federal Conference of Labor Women was convened at the Melbourne Trades Hall on 4 March 1929. Most of the delegates attended in a voluntary capacity and raised money to cover their expenses. The Conference resolved to institute a Labor Women's Interstate Executive to promote the organisation of women in the ALP, educate them politically and industrially, coordinate the work of female ALP members, and arrange for Labor women to be adequately represented at conferences. ${ }^{20}$ The Labor women received little help from the WA State Executive in pursuing these aims. Despite having one female representative, May Holman, in the Legislative Assembly from 1925 to 1939, Labor women undertook less Party political activity during this period than they had before World War I. Most of the matters that concerned them were of immediate importance to the daily lives of women and children. This trend would increase after World War II.

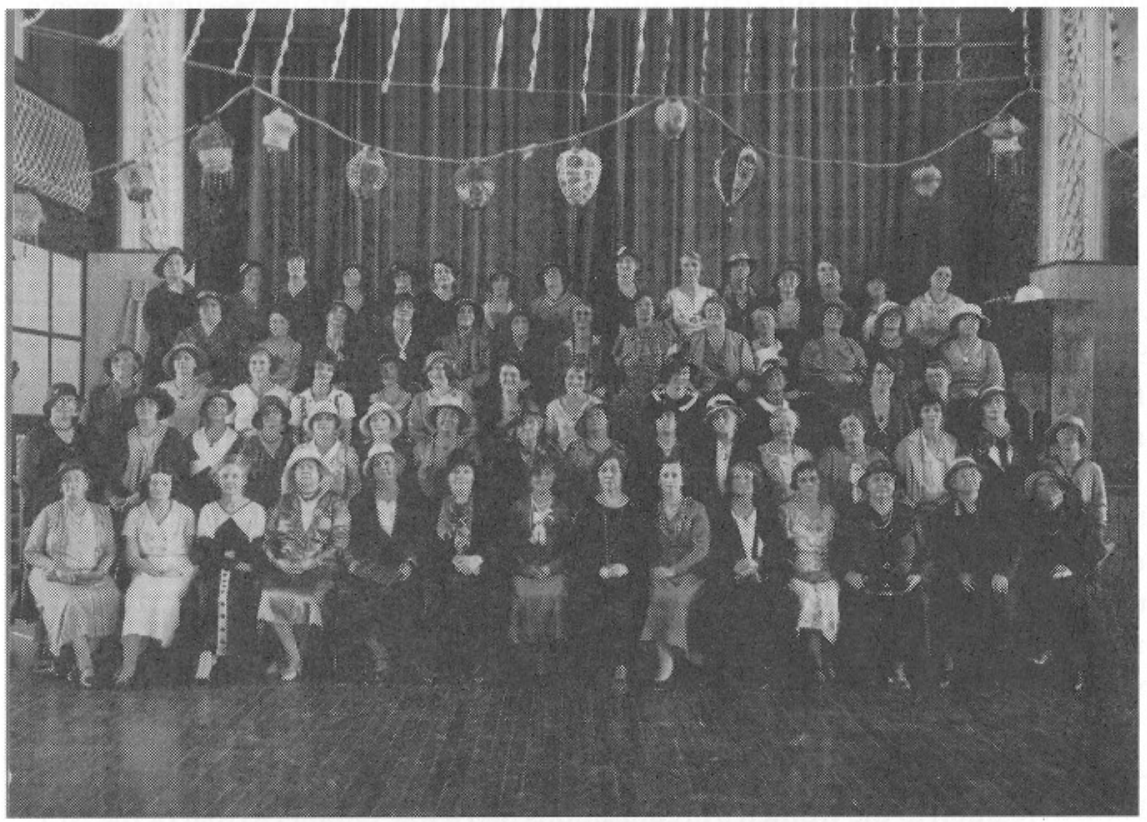

Unity Hall in the Perth Trades Hall building was the venue for most of the annual Labor Women's conferences. This group (c. 1936) includes Jean Beadle and May Holman MLA, front row, seventh and eighth, respectively, from the left.

(Courtesy of the ALP, WA Branch).

During the 1940s, the women made little or no progress towards increased representation in the Labor movement. Pioneers such as Jean Beadle, Adelaide Mannion, Jessie McCallum and Etta Hooton died or retired, and a new generationMolly Holmes, Rose Fuhrmann, Rae Golding and others - were still finding their feet in what was to prove the most challenging of political eras for the ALP. In 1950, the ALPState Executive endorsed a restructuring of the LWCE. The enlarged Central
Executive included one fe branch with female memb and the President and representatives appointec ballot at the Annual Labor Vice Presidents, a Secretar and four from country di

On 23 October 1951, Conference, which was Secretary praised the con in the Federal Referendur Rose Fuhrmann, Vice Pr Hart occupied platform: whether they actually sp on the platforms has ad We have long felt the $n$ Party'. ${ }^{22}$ But those who rejoiced in the knowled Johnson and their collea many more audiences grandiose assertions ba woman was the man's alongside the men', $t$ encouraged them to do

Labor women conti concessions towards Conference passed a r Constitution, entitling They believed that the movement to have a cl as a whole' ${ }^{23}$ The Con

The 1950s was a d too. The LWCE experi Interstate Executive. C been ignored, and deta delegates to attend, or and Golding represent Melbourne in October sending a cheque for Branch, who saw it conferences in the Lab that 'no complaint' ha it was not increased. sending representativ as street stalls, raffles a When the Labor Wo Melbourne on $30 \mathrm{Ap}$ any funds to assist th 
and Senator Dorothy Tangney represented the ALP's Metropolitan District Council..$^{26}$ These women were on Parliamentary salaries, and it is likely that they paid their own expenses.

At the 1959 Women's Interstate Executive, the LWCE was given a new title, the Federal Labor Women's Organisation. The Interstate body in Western Australia became the Labor Women's Central Organising Committee. There was a national biennial conference and women were encouraged to take part in Federal ALP bodies. Delegates travelling interstate could be assisted from a central fund. ${ }^{27}$ At last, it seemed, the Federal Labor women's movement might speak with a unified, national voice.

\section{'Bringing into being a better world'}

The greater part of the Labor women's effort had always been directed into those activities labelled by the Westralian Worker as 'bringing into being a better world'. At the first Labor Women's Conference, held in Perth in October 1912, the delegates passed a wide range of resolutions aimed at protecting children, instituting better working conditions, improving educational and health facilities, and increasing the old age pension. They resolved that people who had committed sexual crimes against children should be 'segregated for life' - rather than being punished by whipping and that legislation was needed to prevent children under the age of 16 years collecting money. They recommended the establishment in Western Australia of a State Children's Council along the lines of a body existing in South Australia. They wanted the minimum age of apprentices raised from 14 to 16 years and their working week reduced to a maximum of 40 hours. The delegates also resolved that the maximum working week for men and women should be 44 hours. The standard working week at that time was 48 hours, although many employees, including women, worked a 52-hour week, or longer. The Conference also asked the State Government to give its employees equal pay for equal work, and to secure this move with legislation.

The delegates resolved to urge the Scaddan Labor Government to bring about radical changes to the education system. They advocated limiting classes to fewer than 40 children, providing free books and medical and dental treatment, introducing open air classes during summer months - in the belief that this was beneficial to the children's health - and including Australian history in the curriculum. Other resolutions urged the government to provide nursing and medical attendance in the home, and a motherhood allowance for needy women during the latter stages of pregnancy and the early life of the infant, in order to stem the high rate of infant mortality in Western Australia. This may also have been an attempt to prevent women returning to work and 'farming out' their babies - sometimes to unscrupulous women who failed to administer proper care. The delegates also wanted intellectually disabled children to be separated from adults by the provision of a cottage in the grounds of the Claremont Asylum. They also recommended the erection of a ward where 'suspected lunatics' could be assessed by expert authorities without suffering the trauma of being admitted to a ward for the insane. ${ }^{28}$

During and after World War I, a number of legislative amendments enacted in the State Parliament were significant steps in the process of making women full citizens, and increased their opportunities for voluntary service in the labour

movement and Act permitted The Justices Ac with men. Jean women who se Books show th heard the who rape, stealing with child neg or of returned in the care of they often rer was reform ra a second char

In 1921, E after she won Cowan's Leg profession, $b$ in a voluntar Justices Asso But the wom Magistrates Horan. A car of their judg Horan's app and 'less wc not reinstate were permi

The LW legislation s the conditic were emplo no protecti Surprisingl boys' healt by staging Green repc environme quarters ha and work conditions 33), but nc an attemp to pass the The LV campaign female gy 
litan District Council. ${ }^{26}$ ly that they paid their

s given a new title, the in Western Australia . There was a national in Federal ALP bodies. ntral fund. ${ }^{27}$ At last, it with a unified, national

zen directed into those being a better world'. ber 1912, the delegates dren, instituting better ties, and increasing the d sexual crimes against anished by whipping er the age of 16 years Western Australia of a South Australia. They rears and their working also resolved that the 4 hours. The standard employees, including :e also asked the State rk, and to secure this

rnment to bring about niting classes to fewer treatment, introducing is was beneficial to the he curriculum. Other medical attendance in luring the latter stages i the high rate of infant an attempt to prevent bies - sometimes to re. The delegates also adults by the provision also recommended the d by expert authorities or the insane..$^{28}$ mendments enacted in of making women full service in the labour movement and in the wider community. A 1915 amendment to the State Children's Act permitted the appointment of male and female voluntary Special Magistrates. The Justices Act (1919) appointed women as Justices of the Peace on equal terms with men. Jean Beadle, Alice Rapley and Adelaide Casson were three of the Labor women who served voluntarily in both capacities. The Children's Court Evidence Books show that the Special Magistrates were rostered to sit on a regular basis and heard the whole range of cases including maintenance dodgers, neglected children, rape, stealing and truancy. Initially, many of the women who appeared charged with child neglect and 'living immorally' were the wives of men on active service, or of returned soldiers who had deserted them. Most neglected children were placed in the care of the State Children's Department until they were 18 years of age, but they often remained living with their mother. The object of the Children's Court was reform rather than punishment. Frequently, parents were cautioned and 'given a second chance' to prove that they could look after their children. ${ }^{29}$

In 1921, Edith Cowan became the first woman to sit in an Australian Parliament after she won the Legislative Assembly seat of West Perth for the National Coalition. Cowan's Legal Reform Act of 1923 cleared the way for women to enter the legal profession, but the Special Magistrates and the Justices of the Peace always served in a voluntary capacity. In 1925, the female Justices of the Peace formed the Women Justices Association of Western Australia, with Jean Beadle as foundation President. But the women soon lost some of their avenues of influence. In 1929, the voluntary Magistrates were superseded by one male, paid professional Special Magistrate, $F$. Horan. A campaign to reinstate the voluntary Magistrates, asserted that, as a result of their judgements, less than three per cent of boys had re-offended. Since $\mathrm{Mr}$ Horan's appointment, it was claimed, more children had been placed in institutions and 'less work done for the betterment of delinquents'. ${ }^{30}$ But the volunteers were not reinstated. From the mid-1930s, however, a few women Justices of the Peace were permitted to serve on the Family Court bench in a voluntary capacity. ${ }^{31}$

The LWCE adopted an important industrial role in highlighting loopholes in legislation such as the Shops and Factories Act. In 1932, Margaret Green reported on the conditions endured by 'small boys' working in bulk petrol stores. The boys were employed to crawl into the petrol drums and clean them out. They were given no protective clothing and their ordinary clothes wore out 'at a terrible rate'. Surprisingly, Green did not mention the effects of such an occupation upon the boys' health. A decade after female workers at the Esplanade Hotel made history by staging a militant 15-week strike to improve their working conditions in 1921, Green reported that the kitchens of tea-rooms remained the most unsafe working environment that she had encountered. At King Edward Hospital, the maids' quarters had 'dark, filthy walls' and were located next to boilers that threw out heat and worked all night. The LWCE Secretary complained about these appalling conditions to C.J. Latham, Minister for Health in the Mitchell Government (193033), but no changes occurred..$^{32}$ After the return of the Labor Government in 1933, an attempt was made to amend the Shops and Factories Act but the legislation failed to pass the conservative-dominated Upper House in September 1935. ${ }^{33}$

The LWCE launched other campaigns to benefit women and children. Members campaigned for a simpler style of dress for school children, for the appointment of female gynaecologists at Perth Hospital, for heating to be installed in the Ladies 
Retiring Room at the Town Hall - they succeeded in this - and for an increase of the $£ 5$ baby bonus to $£ 10 .{ }^{34} \mathrm{~A}$ major task involved collecting information for a report that was presented at a Special Conference of Unions to Consider Child Endowment, which met in July 1927. Chaired by John Curtin, the report recommended that endowment of $13 \mathrm{~s} 5 \mathrm{~d}$ per week (rather than five shillings) be paid on each child in excess of two children (in the belief that two children were already provided for under the Basic Wage). The Report strongly opposed any move by the Bruce Federal Government to means test endowment or to pay for it by reducing the wages of single or childless workers. The resulting Royal Commission decided against instituting any scheme of child endowment' ${ }^{35}$

Despite such setbacks, the LWO and LWCE members continued to work steadily to achieve social reforms and improve social services. In 1952, the Perth LWO protested strongly against the low rates of old age and invalid pensions, asking the ALP State Executive to make representations to the Government for the same privileges to be granted to civilian widows as to ex-servicemen's widows. The LWCE took the matter up with the Federal Minister for Social Services, Athol Townley, who soon dashed their hopes that a Liberal Government would pay civilian widows the same pensions as those received by war widows. Indeed, Townley thought the civilian widows were doing very nicely on the pittance allowed by his Government:

A widow with one dependent child may ... have an income of $£ 2$ per week, receive the full pension of $£ 312 \mathrm{~s} 6 \mathrm{~d}$ and child endowment of five shillings, making her total weekly income $£ 517 \mathrm{~s} 6 \mathrm{~d}$. A widow with two dependent children may have a total weekly income of $£ 617 \mathrm{~s} 6 \mathrm{~d}$...Whilst it is not possible to accede to this request Ito raise the civilian widows' pension to level of the war widows' pension], your organisation may rest assured that the Government will continue to maintain its close interest in the welfare of the civilian widow and the rates and conditions of pensions will be reviewed from time to time in the light of the financial position. ${ }^{36}$

This inequality between war widows and civilian widows' pensions continued for over 30 years. During the 1960s, the average income of war widows was double that of civilian widows. ${ }^{37}$

The Labor women's emphasis on social issues was in tune with wider ALP concerns in the early to mid-1950s. Labor fought the 1954 Federal election campaign on Menzies' broken promises regarding Social Service provision and, in particular, the notorious 'half-crown budget' of 1953-54 in which the Menzies-Fadden Government raised the old age pension by $2 \mathrm{~s} 6 \mathrm{~d}$ a week and allowed pensioners to earn an extra 10 shillings a week. ${ }^{38}$ The Labor women continued to campaign for a rise in pension rates. In 1960, the Perth LWO's resolutions to the Metropolitan District Council included a request that Social Services provide information on pensioners' entitlements, and a protest against a proposed one shilling increase in rent, which was related to a recent rise in the old age pension. ${ }^{39}$

Many Labor women were involved in a voluntary capacity on the boards of such public institutions as the Fremantle and King Edward Hospitals, infant health clinics, the Sunset Old Men's Home, Child Welfare, the Children's Protection Society, the Native Welfare Council, the Good Neighbour Council, and the United Nations Organisation. Their work through these bodies and the labour movement led

ultimately to si facilities. Some make the city s Council to mak and to provide outside of the persuaded the a blind woman a campaign to 1 so that elderly The Main Road long strides [c elderly people could cross on delay'. ${ }^{41}$ Other included dem buses carry de be installed on the night, in i and Deputy $\mathrm{P}$ pedestrian $\mathrm{cr}$ highways anc ascertain the

Hospital c women's orga penny fee for over $£ 2,000$ fo LWO asked t accommodati mid-1956, the prescribed ar stomach ulce in hospital fe sufferers of $e$ the Aged Sic

Venereal sought evide closure of a that the repo The Departn brothel clost recognised meanwhile, assault, unla related to br of having $\mathrm{ke}$

Reforms quality and 
I increase of the ion for a report Id Endowment, mmended that in each child in y provided for Bruce Federal the wages of cided against

work steadily ie Perth LWO ns, asking the for the same ws. The LWCE thol Townley, rilian widows $y$ thought the Government:

ntinued for was double

wider ALP n campaign particular, es-Fadden nsioners to paign for a tan District ensioners' ent, which boards of ant health on Society, d Nations ment led ultimately to significant social and political changes and to improved services and facilities. Some of the latter involved improvements to streets and traffic flow to make the city safer for pedestrians. They succeeded in persuading the Perth City Council to make a block of busy Hay Street in central Perth into a pedestrian mall, and to provide shelters at bus stops located at the gates of Zoological Gardens and outside of the Department of Social Services in Wellington Street. They also persuaded the City of Perth Health Committee to allow an attendant accompanying a blind woman to public conveniences to use the waiting room free of charge. ${ }^{40}$ But a campaign to have the time allowed for 'walk' signs on intersections to be increased so that elderly people and children could safely cross diagonally was unsuccessful. The Main Roads Department disagreed with the LWO's contention 'that a man taking long strides [could] not complete the right angle crossing in the time allowed'. If elderly people could not make the right angle crossing, the Department said, they could cross one street and then wait for lights on the other street 'without excessive delay'. ${ }^{41}$ Other safety concerns that the Labor women voiced throughout the decade included demanding more severe penalties for drunken drivers, and requests that buses carry destination signs on the back as well as the front, and that flood lighting be installed on pedestrian crossings. A request that street lights be left on throughout the night, in interests of public safety, was rejected by the Minister for Electricity and Deputy Premier, C.D. Nalder. ${ }^{42}$ In 1969, fluorescent lighting was installed on pedestrian crossings in the Stirling, Canning, Great Eastern and Great Northern highways and in major roads around the metropolitan area, but it is difficult to ascertain the extent to which the LWO's campaign influenced this decision. ${ }^{43}$

Hospital conditions and fees featured frequently in the Minutes of the Labor women's organisations. The LWO protested over the introduction in 1954 of a sixpenny fee for visitors at the Perth and Fremantle Hospitals. While the fee raised over $£ 2,000$ for each hospital, the LWO claimed it disadvantaged poor people. ${ }^{44}$ The LWO asked the State Executive to seek the introduction of legislation granting free accommodation for pensioners who were patients at the Royal Perth Hospital. In mid-1956, the Perth LWO complained to the Metropolitan Council when the Hospital prescribed an 'expensive diet ... beyond the means of most patients' as a cure for stomach ulcers. At the same time, they expressed concern at the proposed increase in hospital fees. Other initiatives included the establishment of a society to assist sufferers of epilepsy, and funding the May Holman Memorial Holiday Home for the Aged Sick at Middleton Beach, Albany. ${ }^{45}$

Venereal Disease (VD) was another health issue taken up by the LWO. In 1961, it sought evidence that crimes and the incidence of VD had been reduced since the closure of a brothel in Roe Street in 1958. The Department of Public Health stated that the reported number of VD cases had dropped from 338 in 1951 to 93 in 1960. The Department added, however, that it would be hard to link this decline to the brothel closure, as 'casual' prostitutes were more likely to be diseased than those in recognised brothels, who had regular medical checks. The Police Department, meanwhile, was emphatic that the decrease in 'related crimes' such as indecent assault, unlawful carnal knowledge, rape, and sodomy from 1957-58 to 1958-59 was related to brothel closure, but admitted that since then 18 persons had been convicted of having kept premises for the purpose of prostitution. ${ }^{46}$

Reforms were sought, too, in the food industry to improve hygiene and product quality and safety. The LWO moved for legislation to prohibit bread deliverers 
touching bread with their bare hands, and to ban cigarette or pipe smoking in butchers' shops. They also objected to unhygienic conditions in cafes. At the 32nd Annual Conference of Labor women, delegates achieved the first steps towards setting up a Consumers' Council, which was championed by Ruby Hutchison MLC. ${ }^{47}$ By the late 1960s, this had grown into the non-partisan Consumer Action Council, which aimed to adopt price-reducing strategies and to lobby for legislation to control prices and quality. The Council published newsletters comparing the prices of various commodities in different shops. Prices that were raised suddenly or varied considerably from others were investigated and publicised, with the aim of boycotting expensively priced goods. The five-member executive included Honorary Secretary Ruth Coleman, later a Labor Senator for Western Australia. ${ }^{48}$

As part of its self-appointed role as consumers' watch dog, the Perth LWO sent resolutions to be endorsed by the ALP's Metropolitan District Council, requesting the introduction of legislation compelling manufacturers to mark hazardous toys, such as celluloid dolls, with the warning 'highly flammable'. The LWO also protested against the production of 'substandard' matches, rises in the price of staple foods such as bread, and high postal and telephone charges. In November 1966, the Secretary wrote to the Milk Board requesting that it place 'use-by' dates on milk bottles, but the Board objected on the grounds that 'yesterday's milk would not be sold in country centres'.49 The application of use-by dates to perishable foodstuffs has since become standard practice.

In the early 1950s, the LWCE and the various LWO branches also campaigned for limited citizenship for some indigenous Australians. They passed resolutions calling for the establishment of homes and farm colonies built for 'natives', and the granting of citizen and voting rights to 'half-castes' and Aboriginal men and women who had served in World War II. The women persisted in their requests that the Labor platform should recognise Aboriginal people as equals and 'not something apart' ${ }^{50}$ By the end of the 1950s, the Perth LWO had revised its ideas sufficiently to hold a lengthy correspondence with the ALP Metropolitan District Council on the matter of full citizenship for Aboriginal people. The Perth LWO collected information from various organisations on the decimation of the Aboriginal population since the European invasion. Aboriginal people were not citizens but they were essential workers, 'given insufficient pay to live decently, no education, social or political equality'. The Labor women supported moves by the United Nations Organisation to grant land that Aboriginal people could work 'in their own right or in the cooperative way which fits so well into their background and is proving a success wherever it has been developed' ${ }^{51}$ In 1962, the Perth LWO supported the ALP's call for a referendum to delete the provision of the Australian Constitution 'that did not count Aborigines as people' in the redistribution of Federal Parliamentary seats. ${ }^{52}$ Finally in 1967, after lobbying by numerous groups around the country, the Federal Government called a referendum at which the great majority of voters favoured including Aboriginal people in the Census.

The Labor women also criticised the lack of Aboriginal characters in literature and drama, and drew attention to the difficulties that Aboriginal children experienced within the European-oriented education system. In 1958, a resolution to the ALP Metropolitan District Council requested that the $\mathrm{ABC}$ consider running programs for and about Aboriginal children. On another occasion, the Perth LWO contributed $£ 60$ for bursaries to enable an Aboriginal boy and an Aboriginal girl to continue

their studies ur having the mat

Working Class

Throughout the fund raising a was concerts a: in the early 19 closely resem Cross. ${ }^{54}$ In Wo including col Dependents' members ass women. They the Worker's n brought gifts dress' donate procure secor donations, le describing th the Pindalup lasting six $\mathrm{m}$ pay of $£ 29 \mathrm{~s}$, her children were 'patche old coat. She children, bef

In World undertook to Committee. the annual $\mathrm{I}$ and around many had Committee luncheon $\mathrm{h}$ policy of ch LWO mem 
or pipe smoking in in cafes. At the 32nd e first steps towards by Hutchison MLC. ${ }^{47}$ Imer Action Council, legislation to control paring the prices of d suddenly or varied d, with the aim of e included Honorary istralia. ${ }^{48}$

the Perth LWO sent Council, requesting ark hazardous toys, LWO also protested price of staple foods November 1966, the se-by' dates on milk s milk would not be erishable foodstuffs

les also campaigned passed resolutions 'or 'natives', and the nal men and women eir requests that the and 'not something ideas sufficiently to trict Council on the ollected information al population since they were essential , social or political ations Organisation wn right or in the $s$ proving a success orted the ALP's call itution 'that did not rliamentary seats. ${ }^{52}$ country, the Federal of voters favoured

racters in literature hildren experienced olution to the ALP running programs h LWO contributed al girl to continue their studies under the School Bursary scheme. The organisation also succeeded in having the maternity allowance granted to Aboriginal women in $1959 . .^{53}$

\section{Working Class 'Lady Bountiful'?}

Throughout their history, much of the Labor women's energies were directed towards fund raising and palliative work as well as towards changing society. Whether it was concerts and race meetings for which the Goldfields community was renowned in the early 1900s, or the street stalls and raffles mentioned earlier, these activities closely resemble those of volunteers in charitable organisations such as the Red Cross. ${ }^{54}$ In World War I, the Labor women were involved in tasks for the war effort, including collecting money for the Soldiers' Comforts Appeal, the Soldiers' Dependents' Appeal and similar causes. During the Depression of the 1930s, LWO members assembled clothing parcels for the families of unemployed men and women. They either made the clothes themselves or requested donations through the Worker's women's page. At an LWO meeting in May 1931, for example, members brought gifts of baby clothes, including a 'beautiful hand-worked baby's coat and dress' donated by Jean Beadle. Later that winter, the paper reported on efforts to procure second-hand clothes for people in the south-west of the State. To encourage donations, letters from the needy were sometimes published. One woman wrote, describing the plight of her family of six. Her husband had been out of work since the Pindalup mill closed down, and previously, he had been involved in a strike lasting six months. For the last eight months, he had received weekly sustenance pay of $£ 29$ s, of which ten shillings went to pay the rent. The woman explained that her children had no shoes, and their feet were 'all chapped'; the family's underclothes were 'patched until I can patch no more', and she had no winter clothes except an old coat. She requested a warm dress for herself, and night clothes and shoes for the children, before concluding, 'I hope you will not mind me troubling you'..$^{55}$

In World War II, LWO members repeated their roles of the 1914-18 war, and also undertook tasks such as making stretcher covers for the Subiaco Air Raid Precautions Committee. ${ }^{56}$ Throughout the 1950s and 1960s, the women carried the burden of the annual Labour Day luncheon for hundreds of children in various institutions in and around Perth. These children were usually referred to as 'orphans', although many had parents living either in the State or overseas. In 1953, the Labor Day Committee's circular letter stated that the number of 'orphans' catered for at the luncheon had increased from 600 in 1946 to 2,500 in 1952. This increase reflected the policy of child immigration prevalent at the time. ${ }^{57}$ The Committee (which included LWO members) claimed that activities were arranged:

so as to allow the orphans to mix freely with other children at sports so that they do not feel that they are the recipients of charity or subject to any discrimination. Many of these children have never known the happiness of a normal home and we feel that people like ourselves will be glad to give them an opportunity to have an outing like other children of their own age..$^{58}$

This enormous annual commitment by the Labor women continued, unquestioned, until 1967 when the ALP State Executive members saw that times were changing. In a meeting on 1 May, they discussed the possibility of organising a trip to Yanchep 
in the May school holidays. The orphanages had expressed the view that 'the children had plenty of outings and entertainments because so many people had them in their homes at holiday time'. The Labor Day Committee decided that its members would visit various orphanages and give each child 50 cents spending money. There were at least 600 children under 12 and 200 older ones. They also discussed a new movement called 'Birthright' that had been formed to look after the interests of underprivileged children, along similar lines to the Fathers and Sons Movement in the Eastern States. As a result of the change of policy, the orphans were not entertained during the May holidays, but Labor Day Committee members did visit the institutions..$^{59}$

\section{Conclusion}

The 1970s saw the birth of new-style women's organisations, instead of younger women continuing to join the LWO branches in Western Australia. The Women's Liberation Movement was beginning to win new social freedoms and, with the advent of such organisations as the Women's Electoral Lobby and the Harvest Guild (a group formed by the daughters of Women's Service Guild members), the style and method of female political activity changed forever. ${ }^{60}$ With more women in the workforce, the pool of volunteers began to reduce.

What had the Labor women achieved in 70 years of activity? They had sought greater representation in the ALP, yet in 1978, a Committee of Enquiry on 'Women in the ALP' found that, except in the Territories, females comprised less than 10 per cent of the membership of any State Executive, and there was only one women delegate on the National Executive. ${ }^{61}$ Two women had represented the ALP in the State Houses of Parliament and Dorothy Tangney had been the sole female Labor Senator from Western Australia. It was not until 1983 that Wendy Fatin, who had been President of the Federal LWO in the 1970s, became the first Western Australian woman to sit in the House of Representatives.

The Labor women's lack of success in achieving adequate representation in the 70 years covered by this paper, however, should not diminish the their contribution to many aspects of society. In the early twentieth century, by extensive political canvassing, they encouraged other women to take a fuller part in the political processes of the State and the nation by enrolling to vote. They achieved the right for women in sit on juries in the 1950s. Although their lobbying contributed to women workers being granted equal pay for equal work in 1969, this campaign succeeded only after the ALP and Trades and Labor Council began to give it actual support. In showing that women could be involved in public life without detriment to the home and family, they challenged and altered perceptions of the feminine 'sphere'. Those who campaigned for improved working conditions, greater safety measures and shorter hours benefited all workers - not only women and children. Many of the hygiene and safety measures that are now regarded as essential to the production and sale of food, traffic safety, improved health services, and public conveniences and facilities were achieved partially or wholly as a result of campaigns by Labor women and other groups such as the Women's Service Guild and the Consumers' Association. The reforms resulting from these campaigns benefited the whole community.

The Labor women also deserve recognition as workers within the volunteer tradition, for volunteers they certainly were. It is to be hoped that this paper will 
he view that 'the children any people had them in lecided that its members sspending money. There rey also discussed a new ook after the interests of s and Sons Movement in , the orphans were not nittee members did visit

ons, instead of younger Australia. The Women's freedoms and, with the py and the Harvest Guild uild members), the style With more women in the

tivity? They had sought e of Enquiry on 'Women mprised less than 10 per e was only one women resented the ALP in the en the sole female Labor t Wendy Fatin, who had first Western Australian

e representation in the 70 the their contribution to isive political canvassing, political processes of the right for women in sit on J women workers being eeded only after the ALP In showing that women home and family, they Those who campaigned d shorter hours benefited iene and safety measures ale of food, traffic safety, es were achieved partially ther groups such as the le reforms resulting from

rs within the volunteer ped that this paper will encourage further studies on the contribution of voluntary workers within political organisations. Even today, every political party in Australia depends for much of its fund raising, leafleting, and staffing of polling booths on the service given 'cheerfully and unstintingly' by its volunteers.

\section{Endnotes}

1. In Western Australia, the labour organisation originally was called the Australian Labor Federation (ALF). It consisted of affiliated unions and Political Labor Party branches organised into 7-10 District Councils. The State Executive, comprising delegates of these District Councils, met monthly to carry out Party business. The title Australian Labor Party (ALP) was not officially adopted until 1919, but has been used throughout this paper for simplicity.

2. M. Oppenheimer, 'Voluntary Work and Labour History', Labour History, no. 74, May 1998, p. 3.

3. J. Scott, 'Voluntary Work as Work? Some Implications for Labour History', Labour History, no. 74, May 1998, pp. 13-15.

4. Oppenheimer, 'Voluntary Work', p. 3.

5. Cited in ibid.

6. Scott, 'Voluntary Work as Work?', pp. 13-15.

7. Ibid, p. 15 .

8. J. Williams, The First Furrow, The Lone Hand Press, Willagee, 1976, pp. 46-47.

9. Report of the Select Committee of the Legislative Assembly appointed to inquire into the Alleged Existence of Sweating in West Australian Industries, Western Australian Votes \& Proceedings of the Parliament, 1906, Volume II, A 12.

10. Williams, The First Furrow, p. 47.

11. See report of the work of the Eastern Goldfields Women's Labor League in the Westralian Worker, 12 April 1907; also Kalgoorlie Miner, 29 July 1907.

12. Dianne Davidson, Women on the Warpath. Feminists of the First Wave, UWA Press, Nedlands, 1997, p. 27. Davidson says that Beadle joined the Guild in 1914, but does not refer to her activities beyond 1917.

13. See B. Oliver, '"'A Truly Great Australian Woman": Jean Beadle's work among Western Australian Women and Children, 1901-1942', in P. Crawford \& J. Skene (eds), Women and Citizenship: Suffrage Centenary: Studies in Western Australia History, vol . 19, 1999, pp. 87-98.

14. Daily News, 3 September 1969.

15. Westralian Worker, 27 October 1933. The paper's title is taken from this quote.

16. For examples of women serving as Treasurers and Auditors, see Minutes of the State Executive of the ALF (hereafter SE), Battye Library Accession number 1573A/1, 23 July, 6 August, 1910; Westralian Worker, 14 September 1900; Minutes of the Eastern Goldfields District Council (hereafter EGDC Minutes), Battye Library Accession no. 1704/1, 9 January 1911.

17. See reports of the Women's Labor League activities in the Westralian Worker, 1, 22 February 1907, 1, 8 March 1907.

18. Labor Women's Silver Anniversary Souvenir, [1937], p. 18.

19. SE Correspondence, Battye Library Accession no. 1688A/422; LWCE Minutes, Battye Library Accession no. 2011A/2, 5 August 1929.

20. 'Official Statement re First Federal Conference of Labor Women, March 4th-8th 1929', dated 25 May 1929, in SE Correspondence 1688A/321.

21. SE Correspondence 2890A/228, 'Labor Women's Organisation' (LWO).

22. Minutes of the 25th Labor Women's Conference, 23-26 October 1951, held by the ALP (WA).

23. LWO to State Executive, 24 September, 1952, in LWO Papers, held by the ALP (WA).

24. Stuchbury to Chamberlain 12 August 1952 and reply dated 29 August 1952 in SE Correspondence $2890 \mathrm{~A} / 228$.

25. See, for example, Report by the Hon. Secretary (Ethel Selby) to the Thirty Third Labour Women's Conference, 7-10 Sept, 1959 in LWO Papers.

26. LWCE to State Executive, 4 October 1958 in SE Correspondence 2890A/228.

27. Report on the Interstate Executive meeting, Melbourne, 31 March 1959 in LWO Papers.

28. Westralian Worker, 1 November 1912. The difficulties faced by conscientious objectors to the compulsory military training scheme are discussed in B. Oliver, Peacemongers. Conscientious objectors to military service in Australia, 1911 to 1945, Fremantle Arts Centre Press, Fremantle, 1997, pp. 17-28.

29. Children's Court Records, PROWA Accession no. 2495, Evidence Books volumes 2-4, 1916-1920.

30. Unidentified newspaper clipping in Jean Beadle Papers, Battye Library Accession no. 3114A (hereafter Beadle Papers), item 27.

31. This information is from press cuttings in Ibid.

32. LWCE Minutes, Battye Library Accession no. 2011A, Vol. 1, 4 October 1932.

33. See Mooney to Trainer, 13 September 1935, SE Correspondence 1688A/462.

34. LWO Minutes, 19 March, 13, 29 April, 30 June, 14 July 1926. 
35. Chairman of a Special Committee on Child Endowment (report presented at a Special Conference of Unions to consider Child Endowment, Trades Hall, Perth, 27 July 1927, especially pp. 5, 10. (A copy of the report is in Beadle Papers, item 19); also see Westralian Worker, 22 March 1929.

36. Townley to Golding, 12 February 1953, also LWO to State Executive, 12 September 1952, in ALP (WA) Papers, Box 23, file 9, in folders marked '1952' and '1953'.

37. Ann Curthoys, 'Children, Women and Men' in A. Curthoys, A.W. Martin \& T. Rowse (eds), Australians from 1939, Fairfax, Syme \& Weldon Associates, Sydney, 1988, p. 323.

38. See copy of Speaker's Notes for House of Representative election 29 May 1954, ALP (WA) Papers (uncatalogued) Box 3, file 11.

39. Perth LWO Secretary's Report for 1960, in ibid.

40. See Town Clerk to LWO, 14 June 1954 (re public conveniences) in ALP (WA) Papers, Box 3, file 5; Secretary's Report for 1960.

41. Main Roads Department to LWO 5 January 1961, in ALP (WA) Papers Box 3, file 11.

42. LWO General Secretary's Report to affiliated organisations, 30 May 1963.

43. See Question Time 30 September 1969: J. Dolan to Minister for Mines, Votes and Proceedings of the 26th Western Australian Parliament, 1969-70, Vol. 1.

44. Correspondence c. March 1954 in ALP (WA) Papers Box 3, file 5.

45. LWO to ALP Met. District Council, 24 July 1956 and other dates, ALP(WA) Papers Box 3, file 8.

46. ALP Met. District Council to LWO, 24 November 1961; Department of Health Report, 30 October 1961 in ALP (WA) Papers Box 23, file 3.

47. ALP (WA) Papers, Box 3 , file 4 .

48. See Constitution of the Consumer Action Council and Consumer Action Newsletters, Trades \& Labor Council (TLC) Papers, Battye Library Accession no. 3492A, Box 35, File 172,

49. Milk Board to Perth LWO, 18 November 1966, in ALP (WA) Papers, Box 3, file '1967'

50. Bundle of newspaper clippings marked 'Nov 1952', unidentified, in ALP (WA) Papers, Box 3.

51. Folder of correspondence with Metropolitan District Council (1959) and typed material advocating citizenship and civil rights for Aboriginal people, in ALP(WA) Papers Box 23, file 2. The figure ' 300,000 ' is, of course, now regarded as a considerable under estimate of the actual numbers of the Aboriginal population c. 1788.

52. LWO to Chamberlain, 20 July 1962, in ALP (WA) Papers, Box 23, file 4 ('1962')

53. Report of LWO activities to 31 August 1959 in ALP (WA) Papers Box 23, file 11.

54. See Scott, 'Voluntary Work', p. 13, on the role of Red Cross volunteers in Queensland at the beginning of the Depression.

55. Westralian Worker, 21 August 1931, p. 6; also 10, 17, 24 April and 8 May 1931 for clothing appeals.

56. 'Achievements of the LWO' typed notes in LWO papers Box 3, file 9 file, '1957'.

57. There are numerous recent studies of child migration including B.M. Coldrey, Good British stock: child and youth migration to Australia, National Archives of Australia, Canberra, 1999 and A.

Howard, After Barnardo: the phenomenon of child migration from Tilbury to Sydney, 1921-1965, Tarka Publishing, Dangar Island ,1999.

58. Labor Day Committee circular letter 16 January 1953 in ALP (WA) Papers Box 23, file 10.

59. Handwritten attachment to SE Minutes 1 May 1967; also LWO Secretary's Reports 31 December 1966 and 1967 in Ibid.

60. Davidson, Women on the Warpath, p. 274

61. Australian Labor Party, Committee of Enquiry. Discussion Paper No. 4. Women in the ALP, Canberra, 1978.

\section{Soldiers of the $V$ \\ Margo B}

The Women's C active in the 19: waterfront strik carrying out vol the union. Rela offering workil international s to the decline increasing inv voluntary labo

The Women's were active pr for the wives there were re around Aust Rockhampto Newcastle, S Fremantle, an were activist unpaid work the intersecti

The WWI and labour $h$ other labour work of the volunteer ws paid to then Their associa has made the has been w relationship subservient : performed $b$

The Won activities of masculine A were often $\mathrm{i}$ and branch especially d 1970 s, mem 